\title{
PEMANFAATAN SEKAM PADI TERAMONIASI SERTA TERBIOFERMENTASI DALAM RANSUM DISUPLEMENTASI DAUN SIRIH (Piper beetle L.) TERHADAP PENAMPILAN ITIK BALI BETINA FASE PERTUMBUHAN
}

\author{
PARTAMA, I. B. G., T. G. B. YADNYA, DAN A. A. A. S. TRISNADEWI \\ Fakultas Peternakan, Universitas Udayana, Denpasar- Bali \\ e- mail: idabagusgaga@gmail.com
}

\begin{abstract}
ABSTRAK
Penelitian ini bertujuan untuk mengetahui pengaruh pemanfaatan sekam padi teramoniasi serta terbiofermentasi dalam ransum disuplementasi daun sirih (Piper beetle L.) terhadap penampilan itik bali betina fase pertumbuhan. Menggunakan rancangan acak lengkap (RAL), dengan lima perlakuan yaitu ransum tanpa sekam padi (A), ransum mengandung $10 \%$ sekam padi (B), ransum mengandung 10\% sekam padi teramoniasi (C), ransum mengandung 10\% sekam padi dan daun sirih (D), serta ransum 10\% sekam padi teramoniasi serta terbiofermentasi dan daun sirih (E). Setiap perlakuan terdiri atas empat ulangan dan setiap ulangan berisi lima ekor itik bali betina, Variabel yang diamati yaitu konsumsi ransum, kecernaan ransum, bobot badan akhir, pertambahan bobot badan, dan feed conversion ratio (FCR). Hasil penelitian menunjukkan bahwa pemberian $10 \%$ sekam padi teramoniasi serta terbiofermentsi dalam ransum yang disuplementasi daun sirih tidak berpengaruh terhadap konsumsi ransum( $(\mathrm{P}>0,05)$, namun dapat menghasilkan bobot badan akhir, pertambahan bobot badan lebih tinggi $(\mathrm{P}<0,05)$, serta FCR yang lebih rendah $(\mathrm{P}<0,05)$ daripada perlakuan yang lainnya. Dari hasil penelitian dapat disimpulkan bahwa pemberian sekam padi teramoniasi yang disuplementasi daun sirih dalam ransum dapat menghasilkan penampilan yang lebih baik daripada perlakuan yang lainnya.
\end{abstract}

Kata kunci: sekam padi teramoniasi dan terbiofermentasi, daun sirih, penampilan, itik bali

\section{THE UTILIZATION OF AMONIATED AND BIOFERMENTED RICE HULL IN DIETS AND SUPPLEMENTED PIPER BEETLE LEAF ON PERFORMANCE OF MALE BALI DUCK IN GROWTH PHASE}

\begin{abstract}
An experiment was carried out to study the effect on the use of amoniated and biofermented rice hull in diets and Piper beele leaf supplemented on performance of male bali ducks in growth phase. A completely randomized design (CRD) was used with five treatments, such as diet without rice hull (A), diets containing 10\% rice hull (B), diets containing 10\% amoniated and biofermented rice hull (C), diets containing 10\% rice hull and Piper beetle leaf (D), diets containing 10\% amoniated and biofermented rice hull and Piper beetle leaf (E). There were five female ducks with four replications in each treatment. The variables observed were diets consumption, degestible of diets, final body weight, body weight gain, and feed convertion ratio (FCR). It showed that $10 \%$ amoniated and biofermented of rice hull fed to the ducks did not give effect to diets consumption $(\mathrm{P}>0,05)$. In contrast, feed digestibility, final body weight, body weight gain were significantly higher $(\mathrm{P}<0.05)$. Moreover, the FCR was lower compared to other treatments. It can be concluded that amoniated and biofermented of rice hull, supplemented Piper beetle leaf can improve performance of male bali duck in growth phase compared to other treatments.
\end{abstract}

Keywords: amoniated and biofermented of rice hull, Piper beetle leaf, performance, bali duck

\section{PENDAHULUAN}

Sekam padi merupakan hasil sampingan daripada penggilingan padi yang hasil utamanya adalah beras. Hasil sampingan (sekam padi) yang dihasilkan cukup berlimpah karena beras merupakan makanan pokok masyarakat Indonesia. Sekam padi sebagai bahan pakan alternatif mempunyai kandungan zat nutrisi adalah $12,5 \%$ air, 3,1\% protein kasar, 29,2\% bahan ekstrak tiada nitrogen (BETN), serat kasar 35\%, 2,7\% 
lemak, dan 17,5\% abudengan kecernaan yang rendah (Lubis, 1992), dan akan berpengaruh terhadap efisiensi penggunaan ransum, maka perlu difermentasi, agar nilai nutrisinya bisa diperbaiki (Bidura, 2007). Salah satu inokulan yang baik digunakan mencerna bahan ransum yang tinggiserat kasar adalah larutan Effective Microorganisms-4 (EM-4) (Wididana dan Higa, 1993). Di dalam larutan EM-4 mengandung hampir 98\% enzim selulitik yang dapat menghidrolisa selulosa menjadi senyawa karbohidrat yang lebih sederhana yaitu glukosa. Yadnya et al. (2007) melaporkan bahwa fermentasi serbuk gergaji kayu dengan larutan EM-4 dan amoniasi urea dapat menigkatkan nilai nutrisi serbuk gergaji kayu dengan data sebagai berikut: terjadi penurunan kadar serat kasar dari 81,91\% menjadi 48,40\%, dan peningkatan kadar protein kasar dari o,90\% menjadi 8,10\%, lemak kasar dari 0,32\% menjadi $2,30 \%$, sedangkan bagaimana pengaruh amoniasi dan biofermentasi larutan EM-4 terhadap nilai nutrisi sekam padi belum diketahui secara pasti, maka dari itu perlu dicoba dalam penelitian, terutama untuk penelitian pada ternak unggas diantaranya adalah ternak itik.

Ternak itik adalah ternak unggas yang sangat mudah beradaptasi dengan lingkungannya, namun produktivitasnya perlu diperbaiki dengan pemberian zat suplemen yang mengandung senyawa antioksidan, diantaranya adalah daun sirih (Piper beetle L.). Surya et al. (2008) melaporkan bahwa daun sirih (Piper beetle L.) mempunyai total fenol dan aktivitas antioksidan cukup tinggi yaitu 1070mg/10oml dan 97,44\%.

Pemberian ransum mengandung sekam padi yang diamoniasi urea dan disuplementasi dengan starbio (Roni et al., 2006) adalah pemberian 5,97\% sekam padi dan urea menghasilkan bobot potong yang lebih rendah daripada perlakun kontrol, namun setelah disuplementasi dengan starbio tidak berpengaruh terhadap bobot potong dan bobot karkas malahan pada persentase karkas terjadi peningkatan secara nyata $(\mathrm{P}<0,05)$. Pemberian serbuk sergaji kayu yang diamoniasi urea dan larutan EM-4 tidak berpengaruh terhadap penampilan itik bali sedang fase pertumbuhan (Yadnya et al., 2007). Yadnya et al. (2006) melaporkan penggantian $50 \%$ dedak padi dengan sekam padi atau serbuk gergaji kayu disuplementasi dengan starpig tidak berpengaruh terhadap efisiensi penggunaan ransum namun dapat memperbaiki kandungan asam urat dalam serum darah itik bali. Yadnya et al. (2014), mendapatkan pemberian $5 \%$ daun srih, daun mengkudu dan daun ubi jalar ungu dapat memperbaiki profil kimia darah itik bali. Susila et al. (2015) mencoba pemberian sekam padi dengan taraf $5 \%, 10 \%$ dan $15 \%$ baik yang terfermentasi atau tanpa fermentasi disuplementasi daun ubi jalar ungu (Ipomoea batatas L.) diperoleh pemberian 10\% sekampadi terfermentasi dan disuplementasi daun ubi jalar dapat meningkatkan efisiensi penggunaan ransum dan dapat memperbaiki profil lipida daging itik bali. Yadnya dan Wirawan (2016) telah meneliti pemberian sekam padi dalam ransum yang mengandung daun mengkudu (Morinda citrifolia L.) disuplementasi dengan multi enzim dan vitamin dapat meningkatkan produksi telur dan memperbaiki profil lipida telur pada itik bali. Berdasarkan hal tersebut di atas maka dilaksanakan penelitian yang berjudul pemanfaatan sekam padi teramoniasi serta terbiofermentasi dalam ransum disuplementasi daun sirih (Piper beetle L.) terhadap penampilan itik bali fase pertumbuhan.

\section{MATERI DAN METODE}

\section{Tempat dan Lama Penelitian}

Penelitian pemanfaatan sekam padi yang diamoniasi urea serta terbiofermentasi bakeri Lactobacillus complex (BLC) dalam ransum disuplementasi tepung daun sirih (Piper beetle L.) dilaksanakan di Desa Guwang, Kecamatan Sukawati, Kabupaten Gianyar, dan berlangsung selama enam minggu.

\section{Itik}

Itik yang digunakan dalam penelitian adalah itik bali umur 12 minggu yang diperoleh dari seorang pengepul itik yang berasal dari Desa Ketewel, Sukawati, Kabupaten Gianyar sebanyak 150 ekor dengan umur dan berat yang homogen.

\section{Kandang dan Perlengkapannya}

Dalam penelitian ini menggunakan kandang sistem battery colony berlantai dua sebanyak 21 petak. Setiap petak kandang mempunyai ukuran panjang $70 \mathrm{~cm}$, lebar

Tabel 1. Komposisi bahan penyusunan ransum itik bali umur $3-12$ minggu

\begin{tabular}{lccccc}
\hline \multicolumn{1}{c}{$\begin{array}{c}\text { Komposisi Bahan } \\
\text { Ransum (\%) }\end{array}$} & A & B & C & D & E \\
\cline { 2 - 6 } Jagung kuning & 55,36 & 49,98 & 49,98 & 49,98 & 49,98 \\
Kacang kedelai & 9,37 & 12,45 & 12,45 & 12,45 & 12,45 \\
Bungkil kelapa & 11,31 & 9,82 & 9,82 & 9,82 & 9,82 \\
Tepung ikan & 10,13 & 8,10 & 8,10 & 8,18 & 8,18 \\
Dedak padi & 13,18 & 9,00 & 9,00 & 8,80 & 8,80 \\
Sekam padi tanpa & - & 10,00 & - & 10,00 & - \\
fermentasi & & & & & \\
Sekam padi & - & - & 10,00 & - & 10,00 \\
terfermentasi & - & - & - & 0,2 & 0,2 \\
Daun sirih & 0,50 & 0,50 & 0,50 & 0,50 & 0,50 \\
Mineral B12 & 0,15 & 0,15 & 0,15 & 0,15 & 0,15 \\
NaCl & 100 & 100 & 100 & 100 & 100 \\
Total & & & & &
\end{tabular}

Keterangan

A: ransum tanpa mengandung tanpa sekam padi dan tanpa daun sirih

B: ransum mengandung 10,00\% sekam padi tanpa fermentasi dan tanpa daun sirih

C: ransum mengandung 10,00\% sekam terfermentasi dan tanpa daun sirih

D: ransum mengandung $10 \%$ sekam padi tanpa terfermentasi dan daun sirih

E: ransum mengandung $10,00 \%$ sekam padi terfermentasi dan daun sirih 
$70 \mathrm{~cm}$, dan tinggi $70 \mathrm{~cm}$. Kandang dilengkapi dengan tempat makanan dan tempat minum yang terbuat dari bilah-bilah bambu yang letaknya di sebelah luar dan juga dilengkapi dengan tempat penampung kotoran serta penampung sisa makanan, serta dilengkapi dengan lampu untuk penerangan di waktu malam.

\section{Bahan Ransum, amoniasi urea dan biofermen- tasi dengan larutan EM-4 (Effective Microor- ganism-4) disuplementasi daun sirih (Piper beetle L.)}

a) Pengilingan sekam padi kemudian diamoniasi urea $1 \%$ dicampur secara homogen kemudian dituangan larutan EM-4 yang diperoleh dari Tohpati Poultry, Denpasar, Bali, yang sebelumnya larutan EM-4 dicampur dengan Urea dan molasis dan diperam selama dicampur secara homogen dan apabila dikepal dengan tangan tidak terlepas maka siap dimasukkan dalam karung goni untuk difermenntasi selama satu minggu. setelah proses fermentasi selesai silage dikringkan kemudian baru dicampurkan dalam ransum yang berisi tepung daun sirih. Kemudian ransum yang terbentuk diambil sampel sesuai dengan perlakuan, setiap perlakuan dengan empat ulangan, sebagian dianalisis proksimat dan sebagian lagi untuk uji kecernaan

b) Daun sirih diperoleh dari pasar Desa Adat Guwang, Sukawati, Gianyar.

\section{Komposisi ransum untuk penelitian}

Ransum terdiri atas jagung kuning, kacang kedelai, bungkil kelapa, dedak padi, tepung ikan, mineral B12, garam dapur $(\mathrm{NaCl})$, dan sekam padi. Sekam padi ada yang tanpa diolah dan ada yang difermentasi dengan larutan EM-4 (Effective Microorganism-4) dan disuplementasi dengan daun sirih (Piper beetle L.).

\section{Rancangan Percobaan}

Rancangan penelitian yang digunakan adalah rancangan acak lengkap (RAL) dengan lima perlakuan yaitu ransum kontrol, ransum tanpa mengandung sekam padi dan tanpa daun sirih (A), ransum mengandung $10,00 \%$ sekam padi tanpa fermentasi dan tanpa daun sirih (B), ransum mengandung 10,00\% sekam terfermentasi tanpa daun sirih (C), ransum mengandung $10 \%$ sekam padi tanpa fermentasi dan daun sirih (D), dan ransum mengandung 10,00\% sekam padi terfermentasi dan daun sirih (E). Setiap perlakuan dengan empat ulangan dan setiap ulangan berisi lima ekor itik bali betina dengan bobot badan awal dan umur yang homogen.

\section{Peubah yang diamati}

1. Konsumsi ransum adalah ransum yang dikonsumsi selama penelitian, ransum yang dikonsumsi dikurangi sisa makanan selama penelitian..

2. Kecernaan ransum (bahan kering) adalah banyaknya ransum yang dikonsumsi (bahan kering) dikurangi oleh ekskreta yang dihasilkan (bahan kering) dibagi dengan banyaknya ransum yang dikonsumsi (bahan kering) dikalikan 100\%

3. Bobot badan akhir adalah bobot badan itik pada saat penelitian berjalan minggu ke enam

4. Pertambahan bobot badan adalah bobot badan pada saat berumur enam minggu dikurangi bobot badan awal (itik berumur tiga minggu).

5. Konversi ransum adalah ransum yang dikonsumsi dibagi dengan pertambahan bobot badan

\section{Analisis Data}

Data yang diperoleh dianalisis dengan sidik ragam dan apabila terdapat perbedaan yang nyata $(\mathrm{P}<0,05)$ diantara perlakuan dilanjutkan dengan uji Duncan (Steel dan Torrie, 1989).

\section{HASIL DAN PEMBAHASAN}

\section{Konsumsi Ransum}

Konsumsi ransum pada itik yang mendapatkan ransum kontrol (perlakuan A) adalah 2284,14 gram/ ekor selama lima minggu(Tabel 2). Pemberian perlakuan $\mathrm{C}$ dan $\mathrm{D}$ dapat meningkatkan konsumsi ransum secara tidak nyata $(\mathrm{P}>0,05)$.Pemberian perlakuan $\mathrm{B}$ dapat meningkatkan konsumsi ransum secara nyata $(\mathrm{P}<0,05)$ sedangkan pemberian perlakuan $\mathrm{E}$ berbeda tidak nyata $(\mathrm{P}>0,05)$ dibandingkan pemberian perlakuan $\mathrm{A}$. Pemberian perlakuan B yaitu 10\% sekam padi tanpa fermentasi dengan adanya serat kasar yang tinggi (35\%) (Lubis, 1992) tidak mampu dicerna oleh enzim yang terdapat pada saluran pencernaan, terutama tidak adanya enzim-enzim memecah serat kasar, seperti enzim selulase (Wirahadikusumah, 1985) untuk mencukupi kebutuhan zat-zat nurisi yang diperlukan maka itik harus mengkonsumsi lebih banyak daripada perlakuan A. Hasil penelitian ini sesuai dengan yang diperoleh Roni et al. (2006), pemberian 6\% sekam padi dapat meningkatkan konsumsi ransum secara nyata $(\mathrm{P}<0,05)$ pada ayam broiler. Fermentasi larutan EM-4 dapat membantu dalam proses pencernaan serat kasar walaupun tidak maksimal atau dengan pemberian senyawa antioksidan seperti daun sirih dapat membunuh bakteri yang patogen sehingga dapat meningkatkan kecernaan dalam ransum, namun belum mampu mencerna serat kasar secara optimal, maka ransum yang 
dikonsum lebih banyak namun tidak berbeda nyata. Sedangkan dengan mengkombinasikan fermentasi dan pemberian zat antioksidan mengkonsumsi ransum mendekati sama dengan perlakuan kontrol.

Tabel 2. Pemanfaatan sekam padi teramoniasi urea serta terbiofermentasi dalam ransum disuplementasi daun sirih (Piper beetle L.) terhadap penampilan itik bali betina fase pertumbuhan

\begin{tabular}{|c|c|c|c|c|c|c|}
\hline \multirow{2}{*}{$\begin{array}{l}\text { Peubah yang } \\
\text { diamati }\end{array}$} & \multicolumn{5}{|c|}{ Perlakuan } & \multirow{2}{*}{ SEM } \\
\hline & A & B & C & D & $E$ & \\
\hline $\begin{array}{l}\text { Konsumsi } \\
\text { ransum (gr/ekor) }\end{array}$ & $2284,14 b$ & $2584,05 a$ & $2294,36 b$ & $2340,32 b$ & $2284,36 b$ & 50,17 \\
\hline $\begin{array}{l}\text { Kecernan ransum } \\
(\%)\end{array}$ & $63,50 c$ & $60,30 d$ & $64,50 c$ & $67,00 \mathrm{~b}$ & $68,50 a$ & 0,467 \\
\hline $\begin{array}{l}\text { Pertambahan } \\
\text { bobot badan (gr/ } \\
\text { ekor) }\end{array}$ & $632,3 b$ & $587,50 c$ & $644,2 b$ & $683,2 a$ & $685,05 a$ & 4,85 \\
\hline $\begin{array}{l}\text { Bobot badan } \\
\text { akhir (gr/ekor) }\end{array}$ & $918,9 b$ & $874,50 c$ & $931,0 a$ & $969,0 a$ & $972,70 a$ & 7,89 \\
\hline FCR & $3,61 \mathrm{~b}$ & $4,09 a$ & $3,56 b c$ & $3,42 \mathrm{c}$ & $3,33 c$ & 0,287 \\
\hline
\end{tabular}

Keterangan:

A: ransum tanpa mengandung sekam padi dan tanpa daun sirih

B: ransum mengandung $10,00 \%$ sekam padi tanpa fermentasi dan tanpa daun sirih

C: ransum mengandung $10,00 \%$ sekam terfermentasi tanpa daun sirih

D: ransum mengandung $10 \%$ sekam padi tanpa fermentasi dan daun sirih

E: ransum mengandung $10,00 \%$ sekam padi terfermentasi dan daun sirih

SEM: Standard Error of the Treatment Means

\section{Kecernaan Ransum}

Kecernaan ransum pada itik yang mendapatkan perlakuan A adalah 63,50\% (Tabel 2). Pemberian perlakuan B dapat menekan kecernaan ransum sebesar $5,03 \%$ secara nyata $(\mathrm{P}<0,05)$ sedangkan pemberian perlakuan $\mathrm{C}$ dapat meningkatkan kecernaan ransum secara tidak nyata $(\mathrm{P}>0,05)$.Pemberian perlakuan $\mathrm{D}$ dan $\mathrm{E}$ dapat meningkatkan kecernaan ransum sebesar $5,31 \%$ dan $7,87 \%(\mathrm{P}<0,05)$ dibandingkan pemberian perlakuan A. Pemberian sekam padi dalam ransum dapat menurunkan kecernaan ransum karena di dalam sekam padi mengandung serat kasar berupa selulosa, hemiselulosa dan lignin yang sukar dicerna oleh enzimenzim dalam saluran pencernaan unggas (Tillman et al., 1986). Pemberian larutan EM-4 dapat meningkatkan kecernaan ransum. Adanya larutan EM-4 yang mengandung enzim selulase, lipase dan protease yang dapat membantu dalam proses pencernaan (Widiana dan Higa, 1993). Adanya daun sirih mengandung senyawa antioksidan yang mampu menetralkan radikal bebas, sehingga ternak menjadi lebih sehat dan proses metabolisme dalam tubuh akan menjadi lebih baik. Adanya zat antioksidan dapat meningkatkan kecernaan ransum. Hasil penelitian sesuai yang diperoleh Susila et al. (2015), fermentasi sekam padi dengan Aspergillus niger serta disuplementasi dengan daun ubi jalar ungu dapat meningkatkan kecernaan ransum serta dapat meningkatkan penampilan pada itik fase pertumbuhan.

\section{Pertambahan bobot badan}

Pertambahan bobot badan pada itik yang mendapatkan perlakuan A adalah 632,3 g (Tabel 2). Pemberian perlakuan $B$ dapat menurunkan pertambahan bobot badan secara nyata $(\mathrm{P}<0,05)$, sedangkan pemberian $\mathrm{C}$ dapat meningkatkan pertambahan bobot badan secara tidak nyata ( $\mathrm{P}>0,05)$, namun pemberian perlakuan $\mathrm{D}$ dan $\mathrm{E}$ dapat meningkatkan pertambahan bobot badan sebesar 5,55\% dan 8,34\% $(\mathrm{P}<0,05)$ daripada perlakuan A. Pemberian $10 \%$ sekam padi dalam ransum dapatmenurunkan pertambahan bobot badan, sekam padi sebagai sumber serat kasar sukar dicerna, sehingga zat gizi yang diserap oleh tubuh berkurang, sehingga berpengaruh terhadap pertambahan bobot badan, namun pemberian larutan EM-4 dan daun sirih dapat meningkatkan kecernaan. Hasil penelitian ini sesuai dengan penelitian yang dilaksanakan oleh Susila et al. (2015), pemberian sekam padi terfermentasi disuplementasi daun ubi jalar ungu dapat memperbaiki pertambahan bobot badan itik bali pada fase pertumbuhan.

\section{Bobot badan akhir}

Itik yang mendapatkan perlakuan kontrol atau ransum tanpa sekam padi menghasilkan bobot badan akhir adalah 918 g/ekor(Tabel 2). Pemberian perlakuan B dapat menurunkan bobot badan akhir sebesar 4,83\% $(\mathrm{P}<0,05)$, sedangkan pemberian $\mathrm{C}$ dapat meningkatkan bobot badan akhir secara tidak nyata $(\mathrm{P}>0,05)$, namun dengan pemberian perlakuan $\mathrm{D}$ dan $\mathrm{E}$ dapat meningkatkan bobot badan akhir secara nyata $(\mathrm{P}<0,05)$ masing-masing sebesar $5,45 \%$ dan 5,85\% dibandingkan dengan perlakuan A. Bobot badan akhir sangat ditentukan oleh kandungan nutrisi dan jumlah ransum yang dikonsumsi serta kecernaan ransum. Pemberian perlakuan E menghasilkan bobot badan akhir yang lebih baik dari pada perlakuan yang lainnya karena adanya biofermentasi bacteri Lactobacillus complex yang dapat meningkatkan kecernaan dan adanya daun sirih dapat meningkatkan kecernaan dan penyerapan zat nutrisi. Hasil penelitian didukung oleh penelitian yang dilakukan Susila et al. (2015), pemberian sekam padi yang terfermentasi Asperaligillus niger yang disuplementasi daun ubi jalar ungu akan dapat meningkatkan kecernaan yang disertai dengan peningkatkan bobot badan pada itik bali fase pertumbuhan. Hal yang sama juga diperoleh oleh Yadnya dan Wirawan (2016), pemberian sekam padi terfermentasi oleh Starbio dan disuplementasi dengan daun mengkudu (Morida citrifolia L.) dapat meningkatkan penampilan itik bali fase peneluran pertama, termasuk bobot akhir badan itik. 


\section{Konversi ransum}

Konversi ransum pada itik yang mendapatkan perlakuan A adalah 3,61 (Tabel 2). Pemberian perlakuan B dapat meningkatkan konversi ransum sebesar 21,60\% berbeda nyata $(\mathrm{P}<0,05)$, sedangkan pemberian perlakuan $\mathrm{C}$ dapat menurunkan konversi ransum secara tidak nyata $(\mathrm{P}>0,05)$, namun pemberian perlakuan $\mathrm{D}$ dan $\mathrm{E}$ dapat menurunkan konversi ransum masing-masing sebesar 5,26\% dan 8,03\% berbeda nyata $(\mathrm{P}<0,05)$ dibandingkan perlakuan A. Pemberian 10\% sekam padi tanpa fermentasi, dengan kandungan serat yang tinngi sehingga kecenaannya menurun (Anggorodi, 1984) akan berpengaruh terhadap pertambahan bobot badan yang rendah,sedangkan konsumsi ransum yang relatif tinggi yang berpengaruhterhadap konversi ransum. Hasil penelitian ini sesuaidengan yang diperoleh Roni et al. (2006) yaitu pemberian sekam padi tanpa fermentasi menghasilkan penampilan atau FCR yang lebih besr daripada yang lainnya. Susila et al. (2015), pemberian sekam padi terfermentasi Aspergillus niger yang disuplementasi daun ubi jalar ungu (Ipomoea batatas L.) dapat meningkatkan konversi ransum itik fase pertumbuhan.

\section{SIMPULAN}

Berdasarkan hasil penelitian ini dapat disimpulkan bahwa pemberian ransum sekam padi teramoniasi urea dan terbiofermentasi bacteri Lactobacillus complex (BLC) yang disuplementasi daun sirih dapat (Piper beetle L.) dapat memperbaiki penampilan itik bali betina fase pertumbuhan.

\section{UCAPAN TERIMAKASIH}

Penulis mengucapkan ucapan terima kasih kepada Menteri Riset, Teknologi dan Pendidikan Tinggi atas bantuan dana yang telah diberikan melalui Dana Hibah Unggula Perguruan Tinggi melalui Rektor Universitas Udayana/Ketua Lembaga Penelitian dan Pengabdiaan kepada Masyarakat, Universitas Udayana .dengan kontrak penelitian Penelitian Unggulan Perguruan Tinggi TahunAnggaran 2017, Nomor : 416.39/ UN14.4.A/PL/2017 sehingga penelitian dapat berjalan dengan semestinya.

\section{DAFTAR PUSTAKA}

Anggorodi,R. 1984. Ilmu Makanan ternak Umum. Penerbit PT Gramedia, Jakarta.

Bidura, I G. N. G. 2007. Aplikasi Produk Bioteknologi Pakan Ternak. Penerbit Udayana University Press.

Lubis, D. A. 1992. Ilmu Makanan Ternak. PT. Pembanguan, Jakarta.

Roni, N. G. K., N. M.S.Sukmawati,dan N. L. P. Sriyani.20o6.
Pengaruh Pemberian Ransum Mengandung Sekam Padi Diamoniasi disuplementasi dengan Zat Probiotik terhadap Bobot Badan, Perlemakan Yubuh, dan Karkas Atam Broiler. Laporan Penelitian, Fakultas Peternakan, Universitas Udayana.

Steel, R. G. D. and J. M. Torrie. 1989. Priciples and Procedure of Statistic. Mc.Graw,Hill,Book Co Inc, New York, London.

Susila, T. G. O., T. G. Belawa Yadnya, dan N. G. K. Roni. 2015. Upaya Peningkatan Nilai Nutrisi Sekam Padi melaui Amoniasi Urea dan Biofermentasi Aspergillus niger disuplementasi Daun Ubi Jalar Ungu terhadap Penampilan, Kapasitas Antioksidan, dan Kadar Kolesterol Daginga Itik Fase Pertumbuhan, Laporan Penelitian Hibah Unggulam Perguruan Tinggi, Fakultas Peternakan, Universitas Udayana.

Tillman, A. D., H. Hartadi, S. Reksohadiprodjo, S. Prawirokusumo, dan S. Lebdosoekojo. 1986. Ilmu Makanan Ternak Dasar. Gadjah Mada University Press. Fakultas Peternakan. Universitas Gadjah Mada, Yogyakarta.

Wididana, I G. N. dan T. Higa. 1993. Effective Microorgaism4(EM-4). Seri Akrab Lingkungan, Jakarta.

Wirahadikusumah,M. 1985. Biokimia Metabolis Energi, Karbohidrat, dan Lipid. Penerbit ITB, Bandung.

Yadnya, T. G. B. dan N. M. S. Sukmawati. 2006. Pengaruh pengantian dedak padi dengan sekam padi dan Serbuk gergaji kayu tang disuplementasi dengan probiotik terhadap efisiensi penggunaan ransum dan kadar asam urat darah itik Bali. Majalah Ilmiah Peternakan, Fakultas Peternakan, Universitas Udayana, Terakreditasi No. 23a/DIKTI/Kep/2004, Volume 9, nomor 2, Tahun 2006, issn : $0853-8999$.

Yadnya, T. G. B., N. M. S. Sukmawati, dan I K. M. Budiasa. 2007. Pengaruh pemberian serbuk gergaji kayu yang diamoniasi terfermentasi dan daun salam dalam ransum terhadap penampilan, karkas dan kadar kolesterol darah itik Bali. Prosiding Seminar Nasional, Fapet, UGM, Yogyakarta, 24 - 27 Juli 2007.

Yadnya,T. G. B., I. B. Gaga Partama, dan A. A. A. S. Trisnadewi. 2014. Kajian Pemanfaatan Kulit Ubi Jalar Ungu (Ipomoea batatas L) Terfermentasi dalam Ransum terhadap Penampilan, Kualitas karkas, Profil Antioksidan, dan kadar kolesterol Daging Itik Bali. Laporan Penelitian Unggulan Perguruan Tinggi, Tahun Anggaran 2014.

Yadnya,T. G. B. dan I W. Wirawan. 2016. Kajian Pemanfaatan Sekam Padi Mengandung Daun Noni (Morinda citrifolia L.) disuplementasi Multienzim terhadap Kapasitas Antioksidan, Produksi Telur dan dan Kualitas Telur Itik Bali pada Fase Peneluran Pertama. Laporan Penelitian Hibah Unggulan Program Studi, Fakultas Peternakan, Universitas Udayana. Tahun Anggaran 2016. 